YEARBOOK
of ANTITRUST
and REGULATORY
STUDIES
www.yars.wz.uw.edu.pl
Peer-reviewed scientific periodical, focusing on legal and economic issues of antitrust and regulation. Creative Commons Attribution-No Derivative Works 3.0 Poland License.

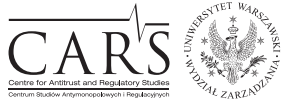

Centre for Antitrust and Regulatory Studies, University of Warsaw, Faculty of Management www.cars.wZ.uw.edu.pl

\title{
Exploitative Abuse of a Dominant Position in the Bulgarian Energy Markets
}

by

\section{Miroslava Marinova and Kremena Yaneva-Ivanova*}

\section{CONTENTS}

I. Introduction

II. Legal background

1. Competition law in Bulgaria

2. Sector specific regulation in Bulgaria

III. Case law

1. Jurisprudence of the EU courts.

2. Decisional practice of Bulgarian competition authority

IV. Conclusions

\section{Abstract}

In the last few years the behavior of undertakings operating in the regulated utility markets, such as energy, water and communications, has been in the focus of the Bulgarian Competition Authority (hereinafter, BCA). Typically, these companies are dominant due to their exclusive licenses to operate in a certain territory and thus the contents of their contractual relationships with customers are often defined in general terms and conditions (hereinafter, GTCs) adopted or approved by the respective sector regulator. Most or all aspects of their pricing policy is also subject to sector regulation.

By analysing critically two landmark decisions of the BCA concerning abuses of companies active in the energy markets, this paper raises the following questions: (1) to what extent the $\mathrm{BCA}$ is competent to intervene and sanction

* Miroslava Marinova, Ph.D candidate in competition law, School of Law, University of Reading, Reading, UK; m.marinova@pgr.reading.ac.uk; Kremena Yaneva-Ivanova, LL.M, Associate at Spasov \& Bratanov Lawyers' Partnership; kremena.yaneva@sbn-law.com. Article received: 2.04.2017; accepted: 30.05.2017. 
those undertakings for conduct which is subject of regulatory control by the sector regulator (the Energy and Water Regulation Commission (hereinafter, EWRC)) and (2) whether in its enforcement practice against those undertakings, the BCA is following the legal standards adopted by the EU courts ${ }^{1}$.

\section{Resumé}

Au cours des dernières années, l'attention de l'Autorité bulgare de la concurrence (ci-après, $\mathrm{ABC}$ ) s'est concentrée sur le comportement des entreprises opérant sur les marchés réglementés des services publics, tels que l'énergie, l'eau et les communications. Typiquement, ces sociétés sont dominantes en raison de leurs licences exclusives pour opérer dans un certain territoire et donc le contenu de leurs relations contractuelles avec les clients est souvent défini dans des termes et conditions générales (ci-après, $\mathrm{CGV}$ ) adoptées ou approuvées par le régulateur sectoriel respectif. La plupart ou tous les aspects de leur politique de prix sont également soumis à la réglementation du secteur. Typiquement, ces entreprises sont dominantes en raison de leurs licences exclusives pour opérer dans un certain territoire et donc le contenu de leurs relations contractuelles avec les clients est souvent défini dans des termes et conditions générales (ci-après, TCG) adoptés ou approuvés par le régulateur sectoriel respectif. La plupart ou tous les aspects de leur politique de prix sont également soumis à la réglementation du secteur. En analysant d'une façon critique deux décisions marquantes de l'ABC concernant les abus d'entreprises actives sur les marchés de l'énergie, ce papier soulève les questions suivantes: (1) dans quelle mesure l'ABC est compétente pour intervenir et sanctionner ces entreprises pour des comportements soumis à un contrôle réglementaire de la part de l'autorité de régulation du secteur (Commission de régulation de l'énergie et de l'eau (ci-après, CREE)) et (2) si dans sa pratique d'exécution contre ces entreprises, l'ABC suit les normes légales adoptées par les courts de l'UE.

Key words: abuse of a dominant position; Bulgarian competition authority; exploitative abuses; energy sector; sector specific regulation

JEL: K21

\section{Introduction}

This article examines the implementation of competition rules in the energy markets in Bulgaria and presents a critical analysis of the decisional practice of the Bulgarian Competition Authority, with focus on two specific decisions.

\footnotetext{
${ }^{1}$ Refers collectively to the Court of Justice (CJ) and the General Court (GC) throughout the text.
} 
In the past few years, the BCA intervened and sanctioned energy companies. This trend reached its peak in 2015, when five out of seven infringement decisions were directed against companies operating on the energy markets. These companies are considered dominant because they hold exclusive licenses for a certain type of business, which means that they face no competition in the relevant market by virtue of law. Thus, their behaviour is not capable to exclude or foreclose any potential or actual competitors from the markets on which they operate ${ }^{2}$. What remains is to check whether such companies could commit exploitative abuses and in what form.

According to its 2015 Annual Report, the BCA intends to continue to focus primarily on markets where there is a sole service supplier in each territory and whose conduct could directly affects the interests of consumers. The best interpretation of this statement is that the BCA intends to investigate markets where a company is dominant because of its exclusive licenses to operate in a certain territory and where consumers are more likely to be harmed. It clearly means that the BCA refers to practices that directly harm consumers, such as exploitative abuses (excessive pricing or unfair trading conditions). Arguably, some of the infringement decisions adopted by the BCA so far could not fit well into the notion of exploitative abuse. The decisions seem to incriminate the dominant position in the energy sector itself even in the absence of any explicit exploitative abuse.

We will analyse below two decisions adopted in the period 2013-2015, dealing with both regulated and non-regulated activity.

Through its decision 506/08.05.2013, the BCA sanctioned the public supplier of electricity in Bulgaria, Energo-Pro Sales, for terminating supplies to a business customer who failed to pay the price for electricity it consumed. Energo-Pro Sales is a company holding an exclusive license for the sale of electricity at a regulated price in North-Eastern Bulgaria.

${ }^{2}$ However, the situation does not preclude accusations of exclusionary practices in connected relevant markets. For example, in several cases, the BCA sanctioned distribution companies for restricting the entry of new capacities of renewable energy into the upstream market for production of energy by delaying or denying access to their distribution grid. Since renewable energy producers do not face direct competition because the entire volume of energy they produce is mandatorily purchased at a preferential price, higher than the market price, and for some other reasons, including the fact that the distribution company does not operate on the upstream market for production of energy, the BCA decisions establishing these infringements were subsequently cancelled by court. For example, judgement no 8050 of 12.06 .2014 under case 2669/2014 of the Supreme Administrative court (three-member panel), upheld by judgement no 11780 of 7.10.2014 under case 10392/2014 of the Supreme Administrative Court (five-member panel). 
More recently, through three separate decisions ${ }^{3}$, the BCA sanctioned electricity distribution companies operating the electricity network at low and medium voltage (LV and MV) in different exclusively licensed areas in Bulgaria for imposing excessive prices for providing access to the pylons of their grid to companies operating at the retail market of the distribution of television programs and internet through cable (referred to as cable operators).

If the intervention of the BCA amounts to over-enforcement, which means that the practice could be considered abusive when it is not, it could discourage the dominant company's incentive to innovate and to provide better services (Motta and de Streel, 2006) ${ }^{4}$ or even may lead some companies to abandon future investments plans or dispose of their current investment in the respective country 5 .

The aim of this article is to evaluate critically the BCA's enforcement practices in the energy markets in Bulgaria and to provoke a discussion on the need some of these practices to be reconsidered. The structure of this article is organised as follows. Section 2 discusses briefly the competition rules on abuses of dominant position in Bulgaria. The other provisions of competition law in Bulgaria are beyond the scope of this article because the undertakings operating in some energy markets are considered dominant due to the exclusive licenses to operate in a certain territory and they are predominantly investigated under the abuse framework. This section also reviews the specific sector regulation in the energy sector in order to clarify the interplay between competition law rules and the regulatory instruments. Section 3 reviews the decisional practice of the BCA in the energy markets with focus on two decisions. Subsequently, it evaluates briefly the standards developed by the EU courts.

On the basis of the findings of the previous sections, the article concludes that the dominant undertakings operating in regulated markets should not be investigated for alleged exploitative pricing or exclusionary abuse based on the price of goods or services or any other trading conditions when these price or terms are not freely determined by those undertakings but subject to a specific sector regulation (set or approved by a sector regulator). Further, the BCA should put some limits on its interventionist appetite to control

3 Decisions 449, 450 and 451 dated 23.05.2015 under file no 501/2013.

4 Motta and de Streel claim that: "Excessive price actions may also undermine the investment incentives of the dominant firms. High prices and profits should be seen in general as the reward for a firm's efforts, innovations and investments, and firms indeed invest and innovate precisely because they are able to appropriate the benefits from their risky investments". See Fletcher and Jardine, 2008; Motta, 2004.

5 According to the publicly available information, the majority shareholders in those three distributing firms commenced international investment arbitration against the Republic of Bulgaria for the lack of adequate protection of their investments at ICSID at the World Bank. 
those markets regardless of the fact that similar competences are granted to the sector regulator. However, although this argument has no legal support at EU level, it has support at the scholarly literature (Motta and de Streel, 2006; Röller, 2008).

\section{Legal background}

\section{Competition law in Bulgaria}

At the end of 2008, the Bulgarian Parliament adopted the new Competition Protection Act (hereinafter, CPA), which ensured full coherence of the national legislation with the European acquis for efficient enforcement of competition rules, including Articles 101 and 102 TFEU $^{6}$. Pursuant to Article 19 CPA, a monopolistic position of an undertaking is a position, according to which the company has the exclusive right to perform a certain type of economic activity by virtue of the law. The term "dominant position" is defined in Article 20 CPA as a position of an entity which, because of its market share, financial resources, opportunities for market access, technology level and business relations with other undertakings, may hinder competition in the relevant market since it is independent from its competitors, suppliers or clients. The possession of a dominant or monopolistic position is not itself prohibited. The CPA prohibits any conduct of undertakings enjoying monopoly or dominant position, as well as the conduct of two or more undertakings enjoying a collective dominant position on the relevant market, that may prevent, restrict or distort competition, such as:

1. Impose directly or indirectly purchase or sale prices or other unfair trading conditions;

2. Limit production, trade and technical development to the detriment of the consumers;

3. Apply dissimilar conditions for equivalent transactions to certain partners thereby placing them at a competitive disadvantage;

4. Make the conclusion of contracts subject to acceptance by the other party of supplementary obligations or to the conclusion of additional contracts, which, by their nature or according to common commercial usage, have no connection with the object of the main contract or with its performance;

6 The new CPA replaced the Law on Protection of Competition of 1998 (repealed). 
5. Unjustified refusal to supply goods or to provide services to actual or potential customers in order to impede their economic activity.

The listing of the possible forms of abuse is not exhaustive ${ }^{7}$ but even if the list is illustrative, an abusive behavior of a dominant company should be capable to distort or harm competition in a market and the potential or actual anti-competitive effect should be capable to harm consumers (Monti, 2009, p. 161).

When the dominant undertaking is engaged in practices that impose unfair prices, consumers can be harmed directly (exploitative abuse). If there is sufficient competition on the market, the dominant company cannot charge supra-competitive prices to its customers. In those cases, the dominant company's behaviour could be focused on foreclosing its competitors (exclusionary abuse). Having foreclosed its competitors, the dominant undertaking can then start charging excessive prices because the competitive constraint imposed by its competitors is removed (van der Wounde, 2008, p. 617,640$)$. In this vein, exclusionary abuses harm consumers indirectly through their anti-competitive effect on the competitive structure (Marinova, 2016, p. 387-408). This position was made clear yet in Continental Can where the ECJ established that consumers may be harmed - either directly, when prices are raised above the competitive level (exploitative abuse), or indirectly, when the competitive structure of the market is damaged (exclusionary/anticompetitive abuse, which reduces competition $)^{8}$.

While exclusionary abuses can be accomplished through various strategies and conduct (predatory pricing, margin squeeze, fidelity rebates, tying, bundling, refusal to deal), exploitative abuses are predominantly abusive pricing 9 , which means imposing of "prices set by a dominant undertaking excessively above the competitive level in order to exploit its customers" (Hou, 2011, pp. 47-70).

The distinction between exploitative and exclusionary behaviour is manifest in the practice of the BCA.

The BCA ascertained previously that in cases of exclusionary abuses, the dominant company operates in two vertically related markets and its behavior is directed to foreclose of actual or potential competitors on the downstream market. The BCA argues that the presence of anti-competitive effects of the conduct of the dominant undertaking is associated with foreclosure of actual

${ }^{7}$ ECJ judgement of 21.06.1972, Case 6/72 Europemballage Corporation and Continental Can Company Inc v Commission, ECLI:EU:C:1973:22, para 26.

8 Ibidem.

9 Exploitative conduct may raise 'other' than pricing condition but most recent contributions focus on the pricing aspect. For that reason, it is accepted that exploitative conduct is usually called excessive pricing (Paulis, 2008, p. 515). 
or potential competitors in the downstream market. Respectively, in the case of exploitative abuse, the dominant undertaking operates only in the upstream market and its conduct is against the interests of its customers operating in the downstream market, creating a risk of harm to effective competition between them ${ }^{10}$.

From the decision of the BCA it appears that the criteria distinguishing between exploitative and exclusionary abuses depend mainly on the level of the market in which the dominant undertaking operates - whether it operates in both vertically related markets or just in the upstream market. This view is subject to criticism because the markets in which the dominant undertaking operates are not relevant to determine the type of abuse. Exclusionary abuses could occur when the dominant company forecloses its competitors in the same market ${ }^{11}$. A typical example is so-called "predatory pricing". An approach of the BCA that exploitative abuses create a risk of harming effective competition between its customers operating in the downstream market is also not acceptable. Exploitative abuses create direct harm to the customers of the dominant undertaking and the question of how those non-end customers ${ }^{12}$ compete with each other in the downstream market is irrelevant. Such novel theory introduced by the BCA associating the exclusionary effects (in the downstream market in which the dominant undertaking does not participate) with exploitative behaviour (at the up-stream market) will be further criticized in the below analysis.

In another decision of the BCA, an exploitative abuse is defined as a unilateral behavior of a dominant company, which obtains benefits that it would not be able to achieve if the market in which it operates was competitive. ${ }^{13}$ This definition is closer to the essence of exploitative abuses, which, as we shall see below, is aimed at directly harming consumers.

When the dominant company is engaged in exploitative abuse, it takes advantage of its position to impose on its customers prices that are unreasonably high in view of the economic value of the product or service and prices would not be at that level if the market were competitive. In those situations, the

10 BCA Decision no 843/2013.

11 If a dominant company is active in two or more related markets it may also use its position in one market to abuse on a related market, the so-called 'leveraging' abuses. In those cases a dominant company might foreclose its competitors on the related vertical market. See e.g. CFI judgement of 25.10.2002, Case T-5/02 Tetra Laval v Commission, ECLI:EU:T:2002:264; Commission Decision 88/138/EEC of 22.12.1987, Eurofix-Bauco v Hilti (OJ L 65, 11.3.1988, p. 19).

12 We refer to companies, which purchase goods or services from the dominant undertaking in order to provide their own services to the end consumers. In the analyzed case the cable operators were in such position of non-end "customers".

13 BCA Decision CPC-617/2010. 
dominant company can raise prices unreasonably, and the consumers cannot switch to an alternative supplier (because of the lack of competitors or because an existing alternative supplier is not able to fully satisfy demand, for example due to the lack of capacity). This form of abuse is qualified as exploitative because it results in a direct loss of consumer welfare (O'Donoghue and Padilla, 2014). This is the difference between exploitative and exclusionary abuse in which consumer welfare is damaged indirectly by damaging the competitive structure. It seems that the BCA has difficulties in making this differentiation, which is crucial for the appropriate implementation of the rules of the law of protection of competition in Bulgaria.

Exclusionary and exploitative abuses are identified in the Guidelines of the European Commission's priorities in the application of Article 82 EC (now Article 102 TFEU) ${ }^{14}$. The European Commission recognised that exclusionary conduct harms the competitive process in the internal market and a company holding a dominant position excludes their competitors by means other than competing on the merits of the products or services they provide ${ }^{15}$. Respectively, conduct which is directly exploitative to consumers, for example charging excessively high prices or certain behaviour that undermines the efforts to achieve an integrated internal market, is classified as exploitative abuse $^{16}$. However, there have been very few excessive pricing cases under Article 102 probably due to the European Commission's unwillingness to act as a price regulator ${ }^{17}$.

From the above it is safe to conclude that the competition rules as regards abuse of dominant position in Bulgaria comply with the rules existing in European competition law. The same conclusion cannot be expressed with regards to the BCA's interpretations mentioned above.

\section{Sector specific regulation in Bulgaria}

The Bulgarian Energy and Water Regulatory Commission (EWRC) was established in 1999, based on Article 11(2) of the Energy and Energy Efficiency Act (EEEA) in Bulgaria. The EWRC's main tasks are to regulate the activities in the energy sector, pursuant to Article 21 of Energy Act. The most important powers of the EWRC relate to the licensing of companies

14 Guidance on its enforcement priorities in applying Article 82 of the EC Treaty to abusive exclusionary conduct by dominant undertakings (OJ C 45, 24.2.2009, p. 7-20); hereinafter, Guidance Paper.

15 Guidance Paper, para. 6.

16 Guidance Paper, para. 7.

17 XXVIIth Report on Competition Policy (1997), para. 77. 
active in the energy sector (public suppliers, distribution network operators, traders, the transmission network operator, producers above certain level of installed capacity, etc.), price and costs regulation, approval of GTCs regulating access to the transmission and distribution network and commercial relations with customers, etc. A detailed listing ${ }^{18}$ of all competences is not necessary for the purpose of the present article but what is obvious is that the regulator has a really broad scope of powers to intervene in the energy sector.

The annual report by the EWRC is required to include a statement about preventing distortion and restrictions on competition in energy markets as well as their efficient functioning. This report has to be forwarded to the Agency for the Cooperation of Energy Regulators (ACER) and the European Commission.

From the above it is clear that the activities and pricing policies of the companies operating in the energy market are subject to special sectoral regulation. Therefore, sector regulators have a certain competence to analyze and support the development of competition in those markets. Moreover, according to Article 71 of the Bulgarian Energy Act, the dominant companies charged with the provision of public interest service consisting of transmission or distribution of electricity, heating and natural gas shall be subject to the CPA's provisions to the extent they do not impede de facto or de jure the discharge of their duties. From this provision, one may conclude that the efficient fulfilment of their licensing obligations should have priority over the rules of the CPA.

Additionally, the European Commission in its Guidelines for the Commission's priorities in applying Article 82 of the EC Treaty in the area of abusive exclusionary conduct by dominant undertakings, pays particular attention to the conduct of the companies on the regulated markets. It indicates that in the application of the general principles of enforcement, the Commission will consider the specific facts and circumstances of each case. For example, in the case of regulated markets, conducting its assessment, the Commission will consider the specific regulatory environment ${ }^{19}$.

In one of the very few publications regarding competition law in Bulgaria (whose authors were members and officers of the BCA at that time), presents an interpretation according to which the BCA, in its capacity of a general regulator, is not competent to investigate whether prices of goods or services are "unreasonably high" when such prices are regulated by an independent regulator (e.g. EWRC) (Nikolov et al., 2009). Otherwise, it could lead to the duplication of powers of sector-specific regulators. This understanding is also supported by the authors of this paper.

18 For detailed listing, please refer to: http://www.dker.bg/pageen.php?P=417 (30.05.2017).

19 Guidance Paper, para. 9. 
The provider of regulated services is not free to determine the price for these services and therefore cannot influence the revenues generated by the provision of such services or their cost. In services with regulated prices it is not only the final price of the service, but also the cost of implementation and the calculated profit (margin) as well as the rate of return, which has to be taken into account. We believe that prices which are not set freely by dominant undertakings should not be investigated as an exploitative abuse, since the setting of such regulated price is not an unilateral action of the dominant undertaking but of a state-mandated third party - the sector regulator. Sector regulation is introduced mainly in areas where the consumers need to be protected and there is no sufficient level of competition (otherwise, competition would be expected to promote consumer welfare). If any sector regulator, in principle a government agency, acts in a manner which may be considered anti-competitive, it is the state and not the dominant undertaking which shall be held liable for violation of competition rules.

\section{Case law}

\section{Jurisprudence of the EU courts}

Exploitative abuses have been examined in a limited number of cases, the most prominent of which are United Brands ${ }^{20}$, General Motors ${ }^{21}$, British Leyland $^{22}$ and Port of Helsingborg 23 . The General Motors case was the first in which the European Commission sanctioned a dominant undertaking for imposing excessive pricing ${ }^{24}$. The Commission considered that General Motors' prices were excessive in relation to the economic value of the service. In the subsequent judicial review, the Court of Justice considered whether the prices charged by General Motors was excessive in comparison with prices of competitors and with prices charged by the company in the past. Taking account of the dominant company's explanations, the ECJ annulled the Commission's decision due to lack of sufficient evidence.

20 ECJ judgment of 14.02.1978, Case 27/76 United Brands Company and United Brands Continental BV v Commission, ECLI:EU:C:1978:22.

${ }^{21}$ ECJ judgment of 13.11.1975, Case 26/75 General Motors Continental NV v Commission, ECLI:EU:C:1975:150.

22 ECJ judgment of 11.11.1986, Case 226/84 British Leyland Plc. v Commission, ECLI:EU:C:1986:421.

${ }^{23}$ Commission Decision of 23.07.2004, Case COMP/A.36.568/D3, Scandlines Sverige AB $v$ Port of Helsingborg.

24 26/75 General Motors Continental NV. 
In United Brands, the European Commission reached the conclusion that the price of bananas in Germany was too high, comparing it to the price of bananas of the same supplier in other countries, and the price of bananas from other brands. ${ }^{25}$ The Commission concluded that if the supplier can sell the same product at a lower price in one country with profit, then it follows that charging a higher price on the same product in another country is unfair. Reversing the European Commission's decision, the Court of Justice adopted a standard according to which the Commission had to demonstrate that the price is high not only compared to the price of the product in a neighbouring geographic market but also to establish that the price increased by itself over a specific time period. Thus, the Court raised the question about the comparison between the cost and price of the product as part of the assessment of whether the price is unreasonably high. The Commission's decision was annulled by the Court of Justice due to lack of sufficient evidence supporting the Commission's allegations.

In the most recent decision - Port of Helsingborg, in considering whether prices were excessive in relation to the economic value of the service, the Commission developed a standard of proof explicitly referring to non-cost related factors such as consumer preferences, which bring additional value to the service. The Commission rejected complaints of ferry operators that the port, a dominant operator, charged excessive prices, clarifying the legal standard applicable for excessive pricing ${ }^{26}$.

The standard of proof developed by the Court of Justice may be summarized as follows:

(1) Considering whether the price is excessive by comparison between prices and costs incurred;

Comparing prices and costs to determine excessive pricing is problematic because it might be difficult, if not impossible, to establish costs, especially if the dominant company produces many different products and operates in different markets, since there are no rules on how the businesses should allocate common costs of producing various products. Moreover, difficulties might arise in finding an appropriate benchmark (the most widely applicable is the use of long-run average avoidable cost (LRAIC)). Practical difficulties might occur in establishing a reasonable margin of profit. Finally, this test might not be appropriate in the industries in which the imposition of excessive prices is needed to recover higher initial costs or costs for research and innovation. For that reason, the Court of Justice considered that establishing the

25 27/76 United Brands Company.

${ }^{26}$ Case COMP/A.36.568/D3 Port of Helsingborg, paras 147, 149. 
economic value of the product/service is essential as a second step of the legal standard.

(2) Considering whether the imposed price is unfair per se or compared to the price of competing products;

These judgements clearly show that the application of excessive pricing may constitute an abuse of a dominant position but also that the standard adopted by the Court is very high.

The next section of this paper will analyze the decisional practice of the BCA to clarify whether it has the attribution to intervene and sanction undertakings for conduct, which is subject of regulatory control by the sector regulator, and whether the BCA is following the standard of the EU courts.

\section{Decisional practice of Bulgarian competition authority}

In Decision no 506 of 08.05.2013, the BCA sanctioned a public electricity supplier for the termination of the supply of electricity due to the failure of a commercial customer to pay the price. The customer was the only supplier of water and sewerage services in the relevant market - the district of Dobrich ${ }^{27}$. Hence, its services were of great importance for the local consumers. Pursuant to Article 98a of the Energy Act (EA), the suppliers of electricity, including the defendant, sell electricity under publicly announced GTCs approved by the regulator. The GTCs in question governing the relationship between the parties for the relevant period were approved by the sectoral regulator in its Decision no OU-061/07.11.2007.

According to Article 123 of the EA, the dominant supplier of electricity has the right to suspend the supply of electricity if the client breaches its duties under the contract for sale of electricity, including failing to timely make outstanding payments.

The water and sewage operator in Dobrich (a state-owned company) had permanent difficulties in paying its bills for the supply of electricity on time. Throughout the years the parties signed several agreements that aimed to reschedule the payments. However, the outstanding debt of this client was still exceeding BGN 3 million (approx. EUR 1.5 million). Moreover, the client breached the last rescheduling agreement by not only delaying its monthly installment payments covering old debt, but also by not paying on time the obligations under current invoices.

As a result, the electricity supplier initiated an interruption of its services according to the GTCs. The dominant supplier of electricity fulfilled its

27 The territory of Bulgaria is divided into 28 districts. 
obligations under Article 20 of its GTCs, and made the required written notice to the client containing a warning that if the accumulated debt is not paid within a specified period, electricity supply will be suspended.

In this case the BCA examined whether and to what extent the public supplier had followed the procedure for the suspension of the electricity supply established by the Energy Act and the GTCs to assess whether Article 21 CPA was breached. In our view, in this case, the BCA was trying to appropriate the powers of the sector regulator, which is the competent authority to monitor compliance with the Energy Act and the GTCs. Moreover, there are specific penalties under the Energy Act, which the sector regulator is entitled to impose on the license holder for breach of this procedure. The approach of the BCA is objectionable since it entails at least two risks: it allows one and the same behavior to be assessed for compliance with a certain rule but by different regulators and be found to constitute an infringement of both competition rules and the rules of specific sector regulation, theoretically exposing the dominant company to be sanctioned twice. Such potential accumulation of liability could infringe the basic legal principle non bis in idem.

Another criticism which can be made is in the treatment of a company's exercise of a legal right under a special law as an offense under another law. The underlying position of the BCA was that regardless of the fact that the special sector regulation provides for such a possibility, the suspension of supplies by the dominant company might constitute an abuse in the light of the particular facts of the case. Moreover, according to the BCA, the dominant company should have taken into account the high social importance of the services provided by the client (supply of fresh water) and should have considered a recourse to other methods of debt collection (for example through civil enforcement). The BCA ignored the objection that the special sector regulation and the GTCs did not distinguish between different categories of clients exposed to the possibility of having their supplies suspended based on the nature of their business.

Furthermore, in its decision the BCA placed additional requirements as part of the procedure for implementing the suspension of supply on top of those provided for in the EA and the GTCs. According to the BCA, the public supplier abused its dominant position by failing to provide certain information to the client in advance. This was information about the exact time when the suspension would start/end and about the particular points of supply to which supplies would be suspended ${ }^{28}$. Surprisingly, the BCA's "requirements"

28 The client has more than one site and connection points to the network. In our view, a requirement to indicate in advance the specific points of supply to which the supplies will be suspended has no sense, since the supplier is entitled to suspend the supplies to all sites simultaneously. 
cannot be found either in the EA or the GTCs of the energy company, which govern the procedure in question. Such interpretation of the law which in fact creates new rules rather than assesses implementation, in our view, constitutes inadmissible attempt for appropriation of the powers of the sector regulator by the BCA. The BCA is entitled neither to enact rules in the sphere of energy regulation, nor to extend the scope of the existing rules.

The dominant company argued that the cessation of electricity supply in the case of overdue unpaid bills which is subject to the statutory right cannot constitute an abuse of a dominant position. If there were any violations of the procedure, they could serve as a basis for engaging the administrative liability of the company under the EA but cannot be penalized as a competition infringement. It should be noted that in the analyzed case, the BCA did not indicate which type of abuse had taken place. From The analysis of arguments in the BCA decision allows to conclude that the authority viewed it as an exploitative abuse. However, it was not clear what benefits the dominant company could obtain by suspending the supply to a customer who did not pay for services, except to limit the damages it incurred.

According to the EU case law, refusal of supply has never been classified as an exploitative abuse because as a result of such refusal, the dominant undertaking could not obtain an unfair advantage. This refusal would have anticompetitive effects only if the dominant undertaking on the upstream market and the customer which was refused delivery were competitors in the downstream market. In such a case, the customer cannot operate in this market (the effect is to exclude a competitor). Apparently, due to the impossibility of to justifying an exclusionary abuse due to the absence of competition on the downstream market (not only between the parties, but in general), the BCA did not define the type of abuse. From the above considerations it is obvious that the abuse cannot be defined as either exclusionary or exploitative. The energy supplier suspended supply to the customer because the latter did not fulfill its obligations to pay the bills. The objection of non-performed contract is a fundamental principle in civil legal relations under which each party may refuse to perform its obligation under the contract if the counterparty fails to perform its own ${ }^{29}$. It is a measure self-prescribed by the law, which aimed to limit the damages and to protect the commercial interests of every economic operator (regardless dominant or not).

The main shortcoming of the BCA's decision is that it fails to demonstrate the likely or actual anti-competitive effect of the behavior in question.

The BCA's decision was challenged by the sanctioned company before the Supreme Administrative Court on several grounds, some of which were

29 A form of the Roman exception non adimpleti contractus. 
discussed above $\mathrm{e}^{30}$. Courts of both the first and second instance ruled in favor of the dominant company and repealed the BCA decision. ${ }^{31}$ The Courts found that the market on which a company is dominant may be different from the market on which the abuse has effect, but disagreed with the BCA that the public supplier had not followed the procedure for supply suspension as provided by the EA and the GTCs. The Court analyzed each of the requirements for suspension and how it was complied with, and reached the conclusion that the dominant company exercised its statutory right to suspension "in conformity with the law". Thus, the behavior of the company could not be qualified as abusive. Further, the judgement of the five-member panel said that the behavior of the dominant company had objective justification - the fact that the client was in breach of obligations. It was also noted that the BCA had not explained why the investigated conduct was not qualified under Article 21(5) CPA as refusal to supply, but under the general prohibition.

In the authors' opinion, regardless of this outcome, the judgements in this case have a serious defect in that they did not rule out the possibility of duplication of liability under both energy sector regulation and the general competition regulation. The issue of BCA's competence was not touched upon by the courts and thus the judgments seem to be implying that the BCA is competent to examine compliance of a company's behavior with specific sector regulation. Arguably, there are examples (although not regarding excessive pricing) of the European Commission intervening in national regulated markets where the regulator did not intervene or when it endorsed anticompetitive behavior of a dominant undertaking (Paulis, 2008, p. 520 $)^{32}$. However, many prominent commentators believe that intervention in exploitative cases under Article 102 should be limited only to very special circumstances such as significant barriers to entry, markets unlikely to selfcorrect and where there is no regulation (Paulis, 2008, p. 530; Motta and de Steel, 2008). Others suggested that there is less risk of errors "if the matter is entrusted to a sector-specific regulator" rather than to competition authorities which are "ill-equipped" to intervene in controversial price-related remedies (Forester, 2008).

30 Supreme Administrative Court is the Bulgarian court which reviews appeals against the decisions of CPC in two court instances. The court acts as first court instance in a three-member panel and as second and last court instance sitting in a five-member panel.

31 The final decision of the five-member panel was announced on 13.10. 2016.

32 See Commission Decisions: 2003/707/EC of 21.05.2003, Case COMP/C-1/37.451, 37.578, 37.579 Deutsche Telekom AG v Commission (OJ L 263, 14.10.2003, p. 9-41); of 4.07.2007, Case COMP/38.784 Wanadoo España v Telefónica (OJ C 83, 2.4.2008, p. 6-9); of 16.07.2003, Case COMP/38.233 Wanadoo Interactive. 
One of the main issues raised by the sanctioned company, namely the question of the relevant market on which competition was allegedly hindered by its behavior, was not explored at all and thus left out of the scope of the judgments. If it was an exploitative abuse, why then the BCA justified the anti-competitiveness as negative impact on the interests of the final consumers of the water supplier who were left without water supplies for a day? Shall the dominant company be held liable for the interests of the consumers of a client in breach of its obligations and is it possible to have such indirect exploitation? Such interpretation would put too many responsibilities on the companies acting in the energy sector, including foreseeing and caring about how the relations with their clients may affect the relations between those clients and their consumers.

In very similar decisions issued in May 2015, the BCA sanctioned three regional operators of the electricity distribution network - the local subsidiaries of CEZ, E.ON and Energo-Pro - for imposing unjustified high prices for providing access to the pillars of their distribution grids. The pillars are used by cable operators build networks and provide their services in the retail market of distribution of television programs and internet access.

The Electronic Communications Act (ECA) and the Ordinance No 35 of 03.11.2012 regulates the relations regarding electronic communications and rules and standards for design, construction and commissioning of cable electronic communications networks and related infrastructure. According to Article 281 ECA, the establishment of the electronic communications networks and the facilities infrastructure associated with them is carried out under the Act and under the Territory Development Act. According to section 5 of the same article, the operators have the right to build electronic communications equipment related to the infrastructure on the basis of a written contract with the owner (which in this case is the operator of the distribution network). The operators of the distribution network provide access to their infrastructure on the basis of a rental contract.

According to the EA, only one license for distribution of electricity is granted for a given territory ${ }^{33}$. Thus, each of the three companies had a monopoly for the license activity in the geographic area in which it operated the Medium and Low Voltage network. However, none of those companies operated on the TV and internet retail market. Hence, there is no competition between them and cable operators as far as they operate in different relevant markets.

On the other hand, the BCA correctly observed that low voltage (LV) pillars are built and maintained for the main license activity of the companies, namely

33 For that purpose the territory of the country is divided into three license areas, each consisting of several districts. There is also a fourth distribution company which operates only in a single touristic village. 
the distribution of electricity, while providing cable operators with access to the pillars network was an additional business activity outside of the scope of their license. Being non-regulated, the rental price for access to the pillars was assessed by the BCA in the light of the abuse of dominance prohibition under Article 21 CPA.

In terms of market definition, the BCA held that the pillars of each of the three distribution companies constituted a separate relevant market. Such finding is objectionable since there were other methods and infrastructures for building electronic communication networks, including the underground channel network operated by the national telecommunication incumbent. Moreover, the ECA prohibits building of cable networks in the air in cities of more than 10,000 people and the underground channel is the only legal alternative in such places. The telecommunication incumbent was qualified by the Electronic communication regulator as a company having a significant impact on the market and thus its price for access to the underground channels was regulated. The BCA compared the non - regulated price of the distribution companies and the regulated price of the telecommunication incumbent for building a cable network on a $100 \mathrm{~m}$. distance and held that the difference (within the range of circa $20 \%$ ) was enough to justify that those services constitute a separate market. In addition, the BCA argued that there were small villages where the underground network was not available at all. However, the BCA extended the dominant position of the sanctioned company to the entire licensed territory, without distinguishing between the cities where the underground network had parallel coverage and places where it had not.

In the authors' opinion, this approach is objectionable. The price difference was not large enough to justify defining two separate relevant markets. Further, there had been a migration of operators from the underground network to the pillars in the past due to the lower rental price of the pillars, which undoubtedly signaled interchangeability between them. Most operators used both pillars and underground networks and some of them have stopped to use pillars after having invested in construction of private local underground networks. These networks were totally ignored by the BCA as a possible alternative to the pillars. Thus, the narrow market definition based on qualitative analysis only (ignoring quantitative criteria), led the BCA to the conclusion that each of the three distribution companies had a dominant position regarding the pillars of its grid.

Providing access to the grid was based on lease contracts between the owner of the network and the cable operators. The terms and conditions of the contract were standard, with identical content for different tenants and the price was determined unilaterally by the dominant company. According to the BCA's findings, the price had not been changed since 2008 (2009 for one of the 
accused companies) until the date of the BCA decisions in 2015. Nevertheless, the BCA held that the investigated price was unreasonably high during the whole period of more than 6 years.

In analyzing the costs and methods for setting the rental price, the BCA found that the dominant companies had no internal rules or methods for accounting separately the additional costs associated with this ancillary activity. The BCA found that the dominant company did not maintain accounting of the costs and revenues from the licensed activity separately from those associated with the ancillary non-regulated services they provide, including providing paid access to their pillars. The conclusion of the BCA that the price was unreasonably high was based entirely on the lack of separate accounting. The BCA went further to state that there were no proved costs for the investigated service and thus there were no prices that could be justified in such circumstances. Thus, the competition authority felt free from the burden of proof that the prices were not reasonably related to the costs of the service. On the contrary, the BCA based its conclusions on the inability of the dominant companies to justify their prices.

The approach of the BCA in this case conflicts with its own stance in similar cases in the past and with cases handled by the European Commission and the EU courts.

Firstly, the BCA did not even try to evaluate the economic value of the service in question, regardless of the strong preference the cable operators had for the pillars. Such client preferences are important factor for calculating the economic value according to the Port of Helsingborg case ${ }^{34}$.

The BCA rejected an expert opinion provided by one of the sanctioned companies, which calculated the economically justified price to be higher than the one under investigation. The reason was that according to the BCA, the lack of separate accounting made the conclusions flawed.

Secondly, the BCA ignored the fact that the costs acknowledged for regulatory purposes were quite below the actual costs of the companies, including the costs for operating and the maintenance of the distribution grid. It is a common practice for the sector regulator to approve costs for the licensed activity below the full requested amount in order to keep the regulated prices of the electricity in a socially accepted range. Only those costs which the sector regulator had acknowledged as costs for the licensed activity were covered by the regulated prices. However, the BCA disagreed with the approach of experts who used for their calculations only this uncovered part of the actual costs to avoid double counting and applied to them a percentage representing that part of each pillar which can be used by the cable operators

\footnotetext{
34 Case COMP/A.36.568/D3 Port of Helsingborg.
} 
(ca. 17\%). The BCA insisted that it was not important what costs were approved by the regulator as costs for the licensed activity but what costs the companies accounted as costs for the licensed activity.

In one of the three decisions, the BCA indicated that the experts' model could be applied in the future but not for the past. In this sense, it suggested that the dominant company could apply in the future prices which are higher than the prices under investigation, provided that those practices are supported by the relevant calculations and proper cost allocation. This statement actually showed that the problem was not in the level of the price per se, i.e. its nominal value, but in the method of accounting the costs and calculating the price. Following this approach, it would mean that even a price which is low as a nominal level can be held anticompetitive if an adequate reasoning is absent. This seems to be a too wide interpretation of the notion of excessive pricing.

Finally, the BCA did not conduct the assessment with a view to the settled case law of the EU courts discussed above in section II of this paper.

In the recent case law of the European Commission and the CJ, the infringement in the form of excessive prices is demonstrated not by an isolated analysis of the cost but through a two-step test that includes, first, comparing the price with economic value of the good or service, the so-called 'economic value'. This benchmark is established in the judgment in General Motors, and confirmed in Deutsche Post $A G^{35}$. It is held that the economic value differs from the cost of production and $\cos ^{36}$. When there are not enough details in accounting to determine the economic value of the service, as was the case in Deutsche Post $A G$, the European Commission used an alternative benchmark but it did not reach automatically the conclusion that the price was unfair. Despite the lack of transparency and separate accounting for the different services, the Commission determined the economic value of the service analyzed as a percentage of the price of other similar services provided by the same company. In the case of Deutsche Post $A G$, the European Commission found that the analyzed price is too high because it exceeded by $25 \%$ the economic value of the analyzed service. It was found that excessive or disproportionate costs are also not considered when assessing whether the price is too high, which the BCA also disregarded because its main argument was the distribution of costs between different activities - those that are covered by the license and the additional ones that are not regulated.

35 Commission Decision 2001/892/EC of 25.07.2001, Case COMP/C-1/36.915 Deutsche Post $A G v$ Commission (OJ L 331, 15.12.2001, p. 40-78).

${ }^{36}$ In the decision in case Port of Helsingborg, the European Commission has determined that the method "cost-plus" is not sufficient to determine whether enterprise abusing the price, so the European Commission is looking for what is the economic value of the service provided. 
The BCA refused to compare the price of the dominant company with those of other electricity distribution companies in the country operating in adjacent geographic markets, although this approach was applied by the European Commission in its decision in Case 110/88 Lucazeau v SACEM. In our view, this comparison is an appropriate method, given that the three electricity distribution companies operate in identical socio-economic environments, regulatory framework, social standards and purchasing power of the population. The explanation that these are different geographic markets, and therefore not appropriate to carry out this test, is questionable because this was the position accepted by the $\mathrm{CJ}$ in the cases mentioned above. A price comparison with the regulated price for usage of the underground channels was also refused by the BCA.

In its decision, BCA relied on isolated quotes from the United Brands' judgment, stating that "any other means by which it can be demonstrated excessive pricing" were allowed, but omitting to mention that what stood behind this quote were the methods developed later in the practice, namely: (1) comparing price with the costs; (2) comparison between competitors' prices or in neighboring markets; (3) comparison between the prices for same product in other geographic markets; and (4) a comparison of prices over time.

It should be emphasized that the European Commission did not analyze in any of the cited precedents whether the revenue that the undertaking under investigation realized by the production of other goods or services is sufficient to cover all its costs, including those to produce the investigated service.

From the above it appears that in this case, the BCA failed to prove sufficiently any of the elements of the two-step test developed by the EU Court and therefore its final conclusions cannot be supported. In practice, the BCA justified the breach of Article 21 CPA in a way that is completely unknown in the European practice.

All three decisions were challenged by the sanctioned companies before the competent court. The first judgement was announced in December 2016 and it concerned the CEZ decision. Although it shared the BCA's conclusions on the definition of the relevant market and the dominant position, the Bulgarian Supreme Administrative Court cancelled the BCA's decision on the merits, mainly because an opinion of experts engaged by the Court demonstrated that the price was not excessive - on the contrary, it was below the price suggested by them as fair. The court held that the BCA had transferred the burden of proof to the accused companies by requiring each of them to prove particular costs justifying the prices. This was particularly difficult, since the pillars were the main asset for the companies' licensed activity and thus all costs associated with their maintenance and operation were accounted accordingly. 
The court put forward two additional arguments - there was an independent expert assessment obtained before the investigation, showing similar results and the BCA failed to analyze the market price of the service and to compare it with the prices applied by other companies performing the same service in different geographic markets. The comparison made by the experts showed that the prices of all three distribution companies were quite similar. Moreover, the price in the case at stake was not updated since 2008 .

The Court emphasized that the obligation for separate accounting of the licensed activity, which the company had under Article 37 EA, was subject to control of the sector regulator. The judgment suggests that even if this obligation was breached, this could be a violation of the EA or the tax law but not a competition infringement. This is a very important conclusion, which the authors wish the Court to have expressed more definitely.

At the time of writing, there is a final judgement ${ }^{37}$ in one of the three cases and an appealable judgment of the court of first instance in another one ${ }^{38}$. The main question on which the court should decide is whether the improper accounting may constitute sufficient evidence for the BCA to conclude that given price is unreasonably excessive and thus abusive, or whether even in those cases, the BCA is under the duty to define the economic value of the service and to compare the price with such value. Although not final, the last judgment seems to support the second view. It was held that even if the accounting of regulated activities had not been properly separated from the accounting of the non-regulated activities, it does not mean that the price is per se excessive.

\section{Conclusions}

Regulated energy markets are vulnerable in terms of competition because some of them are still monopolistic. There is an obvious trend of increased competition enforcement towards undertakings operating in those markets which can be explained by the lack of difficulties for the competition authorities to establish a dominant position. The practice of the BCA clearly shows that it finds itself in a good position to investigate and sanction monopolies for all aspects of their commercial activity - both regulated and non-regulated -- and such an approach has not been explicitly rejected by the Bulgarian courts yet.

37 The final judgement in $C E Z$ case was given under case no. $1693 / 2017$, announced on 12.04.2017.

38 Judgement no. 6579 under administrative case no.7616/2015 announced on 29.052017. 
In our view, the attempts to qualify the dominant position as abusive by itself are fundamentally wrong. Further, the dominant undertakings should not be investigated for exploitative pricing or exclusionary abuse based on the price of goods or services or any other trading conditions to the extent those prices or conditions are predetermined or approved by a specific sector regulator.

Even when the companies are investigated for their ancillary non-regulated activities, the competition authorities should pay attention to the specific regulatory context in which such companies operate. The competition authorities should not take the place of the sector regulator and investigate compliance of those companies with the specific rules applicable to their regulated business. Competition law protects different kind of public interests and therefore any overlapping is undesirable and should be avoided. To the extent that there is still scope for intervention, especially when it comes to the non-regulated aspects of the business, the competition authorities of the member states from the last waves of EU expansion, including the BCA, should be guided by the experience of the European Commission in the competition enforcement in regulated market, as well as by the case law of the EU courts.

\section{Literature}

Fletcher, A. and Jardine, A. (2008). Towards an appropriate policy for excessive pricing. In: C.D. Ehlermann and M. Marquis (eds.). European Competition Law Annual 2007: A Reformed Approach to Article 82 EC (pp. 533-546). Oxford/Portland, Oregon: Hart Publishing, https://doi.org/10.5040/9781472560353.ch-019.

Forester, I.S. (2008). Sector specific price regulation and antitrust regulation - a plague on both your houses? In: C.D. Ehlermann and M. Marquis (eds.). European Competition Law Annual 2007: A Reformed Approach to Article 82 EC (pp. 547-574). Oxford/ Portland, Oregon: Hart Publishing, https://doi.org/10.5040/9781472560353.ch-020.

Hou, L. (2011). Excessive Prices within EU Competition Law. European Competition Journal, 7(1), 47-70, https://doi.org/10.5235/174410511795887606.

Marinova, M. (2016). Should the rejection of the "as efficient competitor" test in the Intel and Post Danmark II judgements lead to dismissal of the effect-based approach?. European Competition Journal, 12 (2-3), 387-408, https://doi.org/10.1080/17441056.20 17.1289706.

Monti, G. (2007). EC competition law. Cambridge University Press.

Motta, M. (2004). Competition policy: theory and practice. Cambridge University Press, https://doi.org/10.1017/CBO9780511804038.

Motta, M. and de Streel, A. (2006). Exploitative and exclusionary excessive prices in EU law. In: C.D. Ehlermann and I. Atanasiu (eds.). European Competition Law Annual 2003: What Is an Abuse of a Dominant Position? Oxford/Portland, Oregon: Hart Publishing. 
Nikolov, P., Karlova, R., Antonova, V., Jordanova, L., Jordanova, D., Pangelov, C. (2009). New legal issues on competition protection, Sofia: Trud \& Pravo.

O' Donoghue, R. and Padilla, A.J. (2014). The Law and Economics of Article 102 TFEU. Oxford/Portland, Oregon: Hart Publishing.

Paulis, E. (2008). Article 82 EC and Exploitative Conduct. In: C.D. Ehlermann and M. Marquis (eds.). European Competition Law Annual 2007: A Reformed Approach to Article 82 EC (pp. 515-524). Oxford/Portland, Oregon: Hart Publishing, https://doi. org/10.5040/9781472560353.ch-017.

Röller, L.H. (2008). Exploitative abuses. In: C.D. Ehlermann and M. Marquis (eds.). European Competition Law Annual 2007: A Reformed Approach to Article 82 EC (pp. 525-532). Oxford/Portland, Oregon: Hart Publishing, 10.5040/9781472560353. ch-018.

Woude, M. van der, (2008). Unfair and excessive prices in the energy sector. In: C.D. Ehlermann and M. Marquis (eds.). European Competition Law Annual 2007: A Reformed Approach to Article 82 EC (pp. 617-6420. Oxford/Portland, Oregon: Hart Publishing, https://doi.org/10.5040/9781472560353.ch-022. 